УДК 37.018.1:005.591.452

Ахновська І.О., к.е.н., докторант, доцент кафедри підприємництва, корпоративної та просторової економіки, Донецький національний університет імені Василя Стуса

\title{
СІМЕЙНА ОСВІТА У ПАРАДИГМІ ЕКОНОМІКИ ЗНАНЬ
}

У статті запропоновано підходи до розуміння сутності економіки знань. Економіка, що базується на знаннях, відповідає за створення багатства шляхом накопичення і впровадження знань. У роботі розглянуто одну із сфер економіки знань сімейну освіту. Визначено особливості функціонування ринку сімейної освіти. Сімейна $\epsilon$ особливим соціальним інститутом освіти, який існував й існує паралельно 3 інституціональними формами освіти. Між цими двома формами освіти існують функціональні зв'язки трьох типів: паралельне існування, заміщення та взаємодоповнення. Аналіз літературних джерел з проблем розвитку освітнього ринку в контексті світових інтеграційних процесів дозволяє встановити такі тенденції його розвитку: поступальне впровадження відкритої освіти в традиційну освітню практику; збільшення кількості шкіл $з$ дистанційною формою навчання; забезпечення навчальних закладів якісною відповідною навчально-методичною базою; удосконалення обміну цифровим контентом, системи управління освітою і контролем якості; забезпечення слухачів засобами доступу до навчальних матеріалів відкритої освіти; підвищення рівня якості освіти та освітніх послуг; забезпечення постійного оновлення навчальних засобів та технологій відповідно запитам слухачів. На основі дослідження, що було проведене, проаналізовано перспективи розвитку економіки знань в Україні.

Ключові слова: економіка знань, сімейна освіта, ринок сімейної освіти, домашня освіта.

Рис.2, Табл.1, Літ.29.

\section{Ахновская И.А.}

\section{СЕМЕЙНОЕ ОБРАЗОВАНИЕ В ПАРАДИГМЕ ЭКОНОМИКИ ЗНАНИЙ}

В статье предложены подходы к пониманию сущности экономики знаний. Экономика, основанная на знаниях, отвечает за создание богатства путем накопления и внедрения знаний. В статье рассмотрена одна из сфер экономики знаний - семейное образование. Определены особенности функционирования рынка семейного образования. Семейное образование является особенным социальным образовательным институтом, который существовал и существует параллельно с институциональными формами образования. Между этими двумя формами образования существуют функциональные связи трёх типов: параллельное существование, замещение и взаимодополнение. Анализ литературных источников по проблемам развития образовательного рынка в контексте глобальных интеграционных процессов позволяет установить следующие тенденции его развития: поступательное внедрение открытого образования в традиционную образовательную практику; рост количества школ с дистанционной формой обучения; обеспечение учебных учреждений качественной учебно-методической базой; совершенствование слушателей средствами доступа к учебным материалам открытого образования; повышение уровня качества образования и образовательных услуг; обеспечение постоянного обновления учебных средств и 
технологий в соответствии с запросами слушателей. На основе проведенного исследования, проанализированы перспективы развития экономики знаний в Украине.

Ключевые слова: экономика знаний, семейное образование, рынок семейного образования, домашнее образование.

\section{Akhnovska I.O.}

\section{FAMILY EDUCATION IN THE PARADIGM OF ECONOMICS KNOWLEDGE}

This paper suggests new approaches to understanding the essence of knowledge economy. The economy based on knowledge, is responsible for the creation of wealth through the accumulation of knowledge and implementation them. The article examines the essence of the category of "knowledge economy", considered one of the areas of the knowledge economy - family education. It also identifies distinctive features of family education. Home education is a special social institution of education that existed and exists in parallel with the institutional forms of education. Between these two forms of education there are functional relationships of three types: parallel existence, substitution and complementarity. Analysis of literary sources on the problems of the development of the educational market in the context of global integration processes allows us to establish the following trends in their development: the progressive introduction of open education into traditional educational practice; increase in the number of schools with distance learning; provision of educational institutions with a qualitative relevant educational and methodological base; improvement of digital content sharing, education management and quality control systems; providing students with access to educational materials for open education; improving the quality of education and educational services; ensuring constant updating of teaching aids and technologies in accordance with the demands of the listeners. On the basis of the conducted research, prospects of development of economy of knowledges in Ukraine.

Key words: knowledge, family education, market of family education, homeschooling.

Постановка проблеми. Нещодавно в українському правовому полі з'явилася нова форма здобуття освіти - сімейна (домашня), хоча очікували ії появи дуже давно. Такою формою здобуття освіти $є$ спосіб організації освітнього процесу дітей самостійно їхніми батьками для здобуття формальної (дошкільної, повної загальної середньої) та/або неформальної освіти, при чому відповідальність за здобуття освіти дітьми на рівні не нижче стандартів освіти несуть батьки, а оцінювання результатів навчання та присудження освітніх кваліфікацій здійснюються відповідно до чинного законодавства. Сьогодні у світі відбуваються інформаційні, соціальні та інші зміни, які піднімають освіту на новий рівень і вимагають адекватних змін у системі ії організації, отож, людство має бути готовим до навчання «суспільства Інтернету». Зміна пріоритетів сьогодення передбачає людину в якості головної цінності життя і вимагає від сучасної системи освіти нового підходу, що грунтується на демократичних засадах і принципах особистісно орієнтованої взаємодії. Особистісний підхід визначає визнання дитини активним суб'єктом виховного процесу та $є$ індивідуальним підходом до людини. Найкраще такий підхід реалізується через сімейну освіту, оскільки саме сім'я $\epsilon$ тією необхідною ланкою, де формується світогляд людини i народжується іiі духовність.

В умовах глобалізації світової економіки та підвищення конкуренції зростає роль знань, які стають основною конкурентною перевагою людини в суспільстві. Все більше ми говоримо про економіку знань, що являє собою етап розвитку 
постіндустріальної економіки, в якому знання стають важливим фактором виробництва разом 3 працею, землею, капіталом, підприємницькою здібністю та інформацією, а також відіграють головну роль у тенденціях соціально-економічної трансформації суспільства. Проте, зауважимо на те, що українська наука звернулася до даної проблематики тільки нещодавно.

Аналіз останніх досліджень і публікацій. Актуальним питанням формування і розвитку економіки знань та іiі складових, присвячені наукові праці зарубіжних та вітчизняних вчених, зокрема над розкриттям сутності і розробкою перспектив розвитку економіки знань працювали М.А. Ажажа, Г.А. Андрощук, В.В. Білоцерківець, М.О. Боярська, Н.А. Букало, А.Л. Гапоненко, В.М. Геєць, В.В. Глухов, У.С. Гузар, П. Давенпорт, О.Дорошенко, О.І. Захаров, В.В. Іванова, М.К. Коноваленко, Д.Лук'яненко, О.Лук'яненко, А.В. Ляшенко, Т. В. Матусевич, Л. Мельник, Б.З. Мільнер, Н.О. Подлужна, М.В. Поляков, Н.Є. Рак, М.М. Руденко, Р.В. Сагайдак-Нікітюк, В.Л. Світлична, Л. Семів, Р. Семів, О.В. Старовойт, Ю. Степанов, Т. Стюарт, В. І. Усик, Л.І. Федулова, Р.В. Хусаінов, Ж.О. Шульга, А.Ю. Янченко та інші вчені. Але на сьогодні немає жодної наукової праці, де у парадигмі економіки знань розглядається саме сімейна освіта.

Метою роботи $\epsilon$ дослідження поняття «економіка знань» на основі ретроспективного аналізу наукової літератури з цієї проблеми і з'ясування ролі сімейної освіти у парадигмі економіки знань.

Виклад основного матеріалу. Відповідників англійською мовою для визначення економіки знань використовують багато: здебільшого „knowledge economy”, а також „new economy (нова економіка), „knowledge-based economy” (економіка, що базується на знаннях), „knowledge-intensive industries” (індустрія інтенсивних знань) тощо. Аналіз сучасної наукової літератури свідчить про існування різних точок зору на сутність поняття «економіка знань» (табл.1).

\section{Таблиця 1 - Актуальні підходи до визначення сутності поняття} «економіка знань»

\begin{tabular}{|c|l|}
\hline Джерело & \multicolumn{1}{|c|}{ Визначення економіки знань } \\
\hline Ажажа М.А. & $\begin{array}{l}\text { Економіка, заснована на знаннях, відображає визнання того, що } \\
\text { наукові знання та спеціалізовані унікальні навички їнніх носіїв } \\
\text { стають головним джерелом і ключовим фактором розвитку } \\
\text { матеріального та нематеріального виробництва, забезпечуючи } \\
\text { стійкий економічний розвиток }\end{array}$ \\
\hline Андрощук Г.А. & $\begin{array}{l}\text { Принципово нове утворення, яка має прийти на зміну економіці } \\
\text { винищення й експлуатації природи, економіці сліпого бажання } \\
\text { людини отримати максимум прибутку. Її основою є не } \\
\text { споживацький мотив людини, а прагнення задовольнити свої } \\
\text { потреби таким чином, щоб не завдавати шкоди природі, } \\
\text { сприяючи при цьому їі відтворенню }\end{array}$ \\
\hline $\begin{array}{c}\text { Білоцерківець В. } \\
\text { В., Ляшенко А.В. }\end{array}$ & $\begin{array}{l}\text { Етап розвитку постіндустріальної економіки, за якого інтелект і } \\
\text { перетворюються у вирішальний фактор, який визначає тенденції } \\
\text { виробничої і соціально-економічної трансформації суспільства }\end{array}$ \\
\hline Гапоненко А.Л. & $\begin{array}{l}\text { Економіка, яка створює, розповсюджує та використовує знання } \\
\text { для забезпечення свого росту та конкурентоспроможності }\end{array}$ \\
\hline 4$]$ & \multicolumn{1}{|l}{} \\
\hline
\end{tabular}




\begin{tabular}{|c|c|}
\hline $\begin{array}{l}\text { Геєць В. М. } \\
\text { [5] }\end{array}$ & $\begin{array}{l}\text { Економіка, в якій домінуючим фактором є процеси накопичення } \\
\text { та використання знань; спеціалізовані (наукові) знання, як } \\
\text { повсякденні, стають важливим ресурсом, який поряд } 3 \text { працею, } \\
\text { капіталом і природними ресурсами забезпечує зростання i } \\
\text { конкурентоспроможність економічної системи }\end{array}$ \\
\hline $\begin{array}{c}\text { Глухов В. В. } \\
{[6]}\end{array}$ & $\begin{array}{l}\text { Система загальних уявлень, сукупність досягнень практики, } \\
\text { систему методів створення умов для функціонування } \\
\text { підтримки науково-дослідної діяльності }\end{array}$ \\
\hline $\begin{array}{l}\text { Давенпорт П. } \\
\text { [7] }\end{array}$ & $\begin{array}{l}\text { Термін, що використо-вується для позначення еволюції країн } \\
\text { пе- редовою економікою за останні три десятиліття }\end{array}$ \\
\hline $\begin{array}{c}\text { Захаров O.I. } \\
\text { [8] }\end{array}$ & $\begin{array}{l}\text { Спеціальна галузь загальної економічної науки і практики; } \\
\text { системоутворююча складова, ядро «нової економіки», яка } \\
\text { визначає перспективи і динаміку стійкого розвитку }\end{array}$ \\
\hline $\begin{array}{l}\text { Мільнер Б.3. } \\
\text { [9] }\end{array}$ & $\begin{array}{l}\text { Новий тип розвитку економіки, в якій знання відіграють } \\
\text { вирішальну роль, а їх виробництво є джерелом зростання }\end{array}$ \\
\hline $\begin{array}{c}\text { Старовойт О.В. } \\
{[10]}\end{array}$ & $\begin{array}{l}\text { Сформована під впливом інформаційної революції своєрідна } \\
\text { галузь продукування та функціонування інтелекту - наукових } \\
\text { знань у всіх сферах матеріального та духовного виробництва. } \\
\text { Вона не заміщує знаннями реальне виробництво, а являє собою } \\
\text { якісно нову систему їх використання та запровадження у } \\
\text { практику }\end{array}$ \\
\hline $\begin{array}{c}\text { Степанов Ю. } \\
{[11]}\end{array}$ & 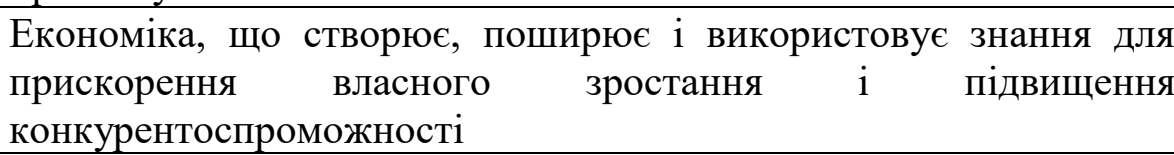 \\
\hline Stewart T.A. [12] & Економіка якості \\
\hline Федулова Л.І. [13] & Новий технологічний рівень господарювання \\
\hline $\begin{array}{c}\text { Шульга Ж.О. } \\
{[14]}\end{array}$ & $\begin{array}{l}\text { Економіка, що створює, поширює і використовує знання для } \\
\text { забезпечення свого зростання і конкурентоспроможності. Це } \\
\text { така економіка, у якій знання збагачують усі галузі, усі сектори і } \\
\text { всіх учасників економічних процесів. Вона не тільки } \\
\text { використовує знання у різноманітній формі, але й створює їх у } \\
\text { вигляді науково-технічної та різноманітної високотехнологічної } \\
\text { продукції, кваліфікованих послуг, освіти }\end{array}$ \\
\hline OECD [15] & $\begin{array}{l}\text { Економіка заснована на виробництві, оновленні, циркуляції, } \\
\text { розподілі і застосуванні знань }\end{array}$ \\
\hline
\end{tabular}

Джерело: систематизовано автором за [1-15]

В.Л. Світлична [16] за результатами аналізу поняття «економіка знань» робить наступні висновки: «економіка знань» у залежності від контексту, розглядається: 1) як частина господарства, яку пов'язано з процесами створення, поширення, використання знань (сектор знань); 2) як самостійний об’єкт дослідження, наука, що вивчає конкретну предметну галузь; 3) як характеристика стану, етапу розвитку економіки й суспільства, при якому знання виступають визначальним фактором іiі розвитку; 4) в широкому розумінні виступає як інноваційна економіка, оскільки тільки знання може бути основою для формування потреби і втілення у життя нововведень; 5) як постіндустріальна економіка, однією з головних рис якої є збільшення питомої ваги сфери послуг у матеріальному виробництві; як інформаційна й глобальна мережева економіка, де знання, втілені у інформацію є головним чинником виробництва. Н.О. 
Подлужна [17] у результаті аналізу існуючих визначень категорії «економіка знань» встановлює, що майже всі автори при розкритті їі змісту роблять акцент на трьох складових: основа економіки знань, за рахунок чого будуть отримані результати в економіці країни; результат, що забезпечує країни досягнення стану економіки знань; можливі процеси, в яких приймають участь знання для забезпечення функціонування економіки знань в країні. Автор зазначає, що основними підходами до визначення сутності економіки знань є такі: економіка знань як тип економіки, як сектор (галузь) національної економіки, як етап розвитку постіндустріальної економіки, як чинник людського розвитку. Зроблено детальний аналіз поглядів різних авторів на існуючі комбінації складу процесів, в яких приймають участь знання для забезпечення функціонування економіки знань у країні.

Вважаємо, що під економікою знань слід розуміти саме етап розвитку інституціональної економіки, де одним з основних факторів виробництва $є$ інтелект.

У зв'язку з тим, що питанням економіки знань приділяли увагу багато вчених, вважаємо також за доцільне зробити ретроспективний огляд наукових напрацювань останніх років стостовно економіки знань. Так, окремо заслуговують на увагу розробки М.В. Полякова [18], зокрема, аналіз рівнів дослідження економіки знань: світового, міжнародного, національного, мезорівня, мікрорівня, індивідуального. Автор пропонує розглядати такі основні процеси в межах економіки знань: 1) отримання знань (придбання вже накопичених і генерування нових знань); 2) абсорбцію знань; 3) передачу знань, яка може протікати на міжнародному рівні; 4) використання знань (переважно для розроблення інновацій та прийняття управлінських рішень). Усі ці процеси супроводжуються економічною оцінкою знань. М.В. Поляков розглядає також головні особливості економіки знань на рівні національного господарства: появу нового способу виробництва, структурні зміни, трансформацію моделі економічного зростання, перетворення національної економічної систем, виникнення спеціальної інфраструктури, появу нового типу підприємництва, цільове інвстування в знання, створення спеціальних інститутів, розвиток ринку знань, зміну характеру праці. Автором також сформульовано напрямки інтернаціоналізації складових національної системи знань та поглиблено уявлення про перехід економіки знань на глобальний рівень.

Н.Є. Рак [19] визначає три головні складові управління знаннями (місця, люди та речі), обгрунтовує фактори управління знаннями (людський, філософський, організаційний, технологічний, системний, глобальний, біологічний, індивідуальний, фактор навчання, фактор часу, ірраціональність знання, раціональність знання). У.Є. Гузар [20] доводе, що на сьогодні існує багато проблем, які потребують суттєвих зрушень, ефективного впровадження фінансових ресурсів у розвиток системи освіти і науки в Україні, а також визначають, що стратегічними завданнями держави, які спрямовуються на їх вирішення, повинні бути: розбудова власної національної інноваційної системи; інтеграція освіти і науки; вдосконалення системи державного фінансування інноваційних процесів; поліпшення та оптимізація змістовної частини вищої освіти, зокрема збільшення частки викладання природничих та математичних наук у структурі навчального процесу, оновлення відповідної навчально-методичної бази, запровадження бюджетного стимулювання цих напрямків; збереження та розвиток вітчизняних наукових та освітянських шкіл, заохочення педагогів-новаторів, технологічне вдосконалення освітніх процесів. Р.В. Хусаінов, А.Ю. Янченко, М.М. Руденко [21] зазначають, що, не зважаючи на розуміння важливості феномену «економіки знань» і досі, більшість країн світу, в тому числі і Україна, недостатню 
увагу приділяють розвитку складових «економіки знань». Індекс знань визначається як середня величина, що складається 3 трьох індексів - освіти, інновацій, інформаційних технологій і комунікацій. Індекс економіки знань являє собою середнє значення чотирьох індексів: індексу економічного стимулу та інституційного режиму, індексу освіти, індексу інновацій та індексу інформаційних технологій і комунікацій. М.О. Боярською [22] проведено порівняльний аналіз головних особливостей традиційних та інформаційних ресурсів, зроблено акцент на інформаційних ресурсах. В.В. Іванова [23] розглядає сутність категорій «економіка знань» та «економіка, заснована на знаннях», а також можливість їх використання щодо характеристики економіки постіндустріального суспільства. Л.І. Федуловою [14] виконано відмінності між такими категоріями, як «традиційна економіка», «інформаційна економіка», «інноваційна економіка», «нова економіка», «економіка знань». Цікавими у даному контексті $\epsilon$ дослідження Л. Мельника [24], який виділяє принципи економіки знань: триєдності природних начал, забезпечення самовідтворення систем, системності життєвого циклу, урахування коеволюції систем, інструменталізації триєдиного еволюційного механізму, оптимізації співвідношення стабільних і змінних компонентів, використання ефекту розширення простору-часу, технологізації трансформацій принцип дематеріалізації трансформаційних процесів (принцип трансформера). Колектив авторів [25] характеризує південно-корейську модель переходу до економіки знань та можливості використання цього підходу в Україні. Н.А. Букало [26] розглядає заходи щодо задоволення потреб споживачів у освітніх послугах вищих навчальних закладів. Л. Семів, Р. Семів [27] розкривають нову роль сучасного університету в умовах економіки знань та євроінтеграції. Р.В. Сагайдак-Нікітюк і М.К. Коноваленко [28] показують роль і значення інтелектуальної ренти в розвитку теорії економіки знань. В. I. Усик і T. В. Матусевич [29] зазначають, що сучасна освіта, основана на економіці знань, поділена на три таких сегменти - той, що фокусується на викладанні; той, в основі якого лежать наукові дослідження та той, який орієнтований на прикладні навички та компетенції. Саме вони складають комплексне уявлення про сферу національної освіти.

На сьогодні у цій сфері - сфері освіти відбуваються зміни, зокрема, на національному рівні - НУШ, щорічні зміни у порядку здачі ЗНО; на глобальному ринку - розповсюдження сімейної освіти. Тенденції розвитку світового ринку освітніх послуг представлено на рис. 1.

Сімейна освіта є особливим соціальним інститутом освіти, який існував й існує паралельно 3 інституціональними (державними, суспільними) формами освіти. Дослідження сучасного ринку сімейної освіти дозволяє виділити наступні його характерні принципи:

— інформаційного дефіциту (спостерігається недостаток інформації щодо юридичних та організаційних питань, обмін інформацією здійснюється в основному через соціальні мережі);

— стратегічної спрямованості (цільові показники та терміни реалізації цілей в основному стосуються розкриття потенціалу дитини та виявлення в неї здібностей);

- системності (навчання відбувається протягом життя, постійно, незважаючи на вихідні чи канікули і розглядається дитиною і батьками вже не як певний процес, а спосіб життя);

— цілісності (життя - це є навчання, а навчання - це життя);

- адаптивності (без традиційної школи батьки і діти самостійно піклуються про соціалізацію дитини у суспільстві); 
- гнучкості (зміна темпів, режимів, пристосування до потреб);

- доступності (багато освітніх центрів і батьків діляться безкоштовними навчальними ресурсами, навчання відбувається також за допомогою відкритої освіти);

- партнерства (батьки часто об'єднують свої ресурси, створюючі сумісні освітні центри, будуючи разом освітні простори - толока);

\begin{tabular}{|c|c|}
\hline \multicolumn{2}{|c|}{ Тендениії розвитку світового ринку освітніх послуг } \\
\hline Глобалізація & Кроскультурність \\
\hline \multirow{2}{*}{$\begin{array}{c}\text { Високий рівень емоційного } \\
\text { інтелекту }\end{array}$} & \multirow[t]{2}{*}{ Розвиток інформаційних технологій } \\
\hline & \\
\hline \multirow{2}{*}{$\begin{array}{c}\text { Урізноманітнення методів та методик } \\
\text { викладання } \\
\end{array}$} & Доступність відкритої освіти \\
\hline & \multirow{2}{*}{$\begin{array}{c}\text { Високі темпи споживання } \\
\text { інформації }\end{array}$} \\
\hline \multirow{2}{*}{$\begin{array}{c}\text { Цінові й нецінові методи } \\
\text { конкуренції }\end{array}$} & \\
\hline & \multirow{2}{*}{$\begin{array}{c}\text { Підвищення рівня культурної } \\
\text { самобутності }\end{array}$} \\
\hline \multirow{2}{*}{$\begin{array}{c}\text { «Відтік мозків» і міграція } \\
\text { суб’єктів освітнього процесу }\end{array}$} & \\
\hline & \multirow{2}{*}{$\begin{array}{l}\text { Легалізація сімейної освіти та } \\
\text { пришвидшення темпів іiі поширення }\end{array}$} \\
\hline Підвищення якості освітніх послуг & \\
\hline
\end{tabular}

Рисунок 1 - Тенденції розвитку світового ринку освітніх послуг Джерело: систематизовано автором

- добровільного залучення та взаємодії (батьки добровільно об'єднують свої ресурси - працю, капітал, час для створення спільних навчальних просторів та взаємодії);

- паритетності (урахування інтересів усіх сторін);

- відсутності ієрархічності (як правило, в таких навчальних просторах навчання будується не на авторитарному авторитеті вчителя, а на дружбі, командній взаємодії, взаємному обміні інформацією та спільному пізнанні);

- ефективності (при сімейному навчанні програма засвоюється учнем набагато швидше);

- прозорості (перед батьками не закривають двері навчального простору, навпаки, батьки є бажаними учасниками процесу, оскільки можуть спостерігати за процесом навчання дитини, приймати активну участь, допомагати власній дитині й іншим членам команди тощо);

- синергії (коли дитина від пасивного користувача освітніх послуг стає активним суб'єктом цього процесу, рівень якості навчання набагато збільшується. У підсумку, обсяг інформації, знань та цікавих здобутків не дорівнює сумі того, що було у вчителя і в учня, а є набагато більшим!);

- автономності (як правило, навчальний процес відбувається автономно від календарного планування, перевірок державних органів тощо, у зручний час для дитини і батьків, відповідно до темпу навчання дитини);

- гнучкості й адаптивності (при сімейному навчанні освітній процес підлаштовано під здоров'я дитини, настрій, психологічні особливості і може бути змінено i 
підкореговано);

- спільного фінансування (часто батьки разом купляють необхідні книжки, канцтовари, матеріали і набори для творчості);

- інноваційності (батьки активно «випробовують» нові методи й методики навчання, інноваційні матеріали);

- участі місцевої громадськості (при створенні навчальних просторів батьки шукають найкращих фахівців у різних галузях і сферах діяльності для розкриття потенціалу власних дітей).

Таким чином, враховуючи ці ознаки, а також в умовах дефіциту інформації стосовно юридичних та організаційних питань, батьки знаходяться в інформаційному вакуумі щодо процесу переходу дитини на домашнє навчання (хоумскулінг). На рис. 2 запропоновано алгоритм прийняття рішення про переведення дитини на домашнє навчання (хоумскулінг).

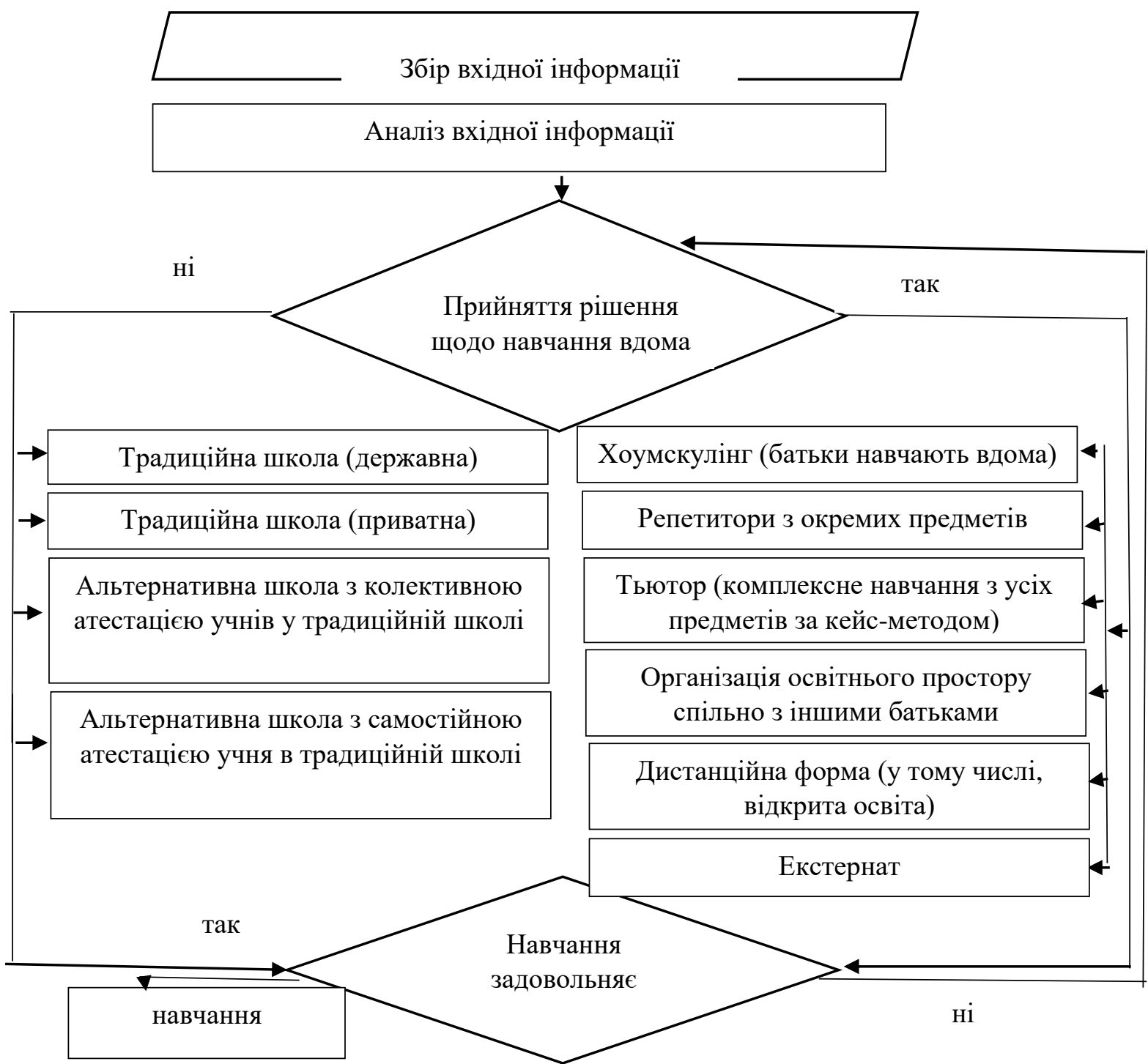

Рисунок 2 - Алгоритм прийняття рішення про перехід на домашнє навчання (хоумскулінг)

Джерело: розроблено автором 
Крім того, будь-який з цих способів передбачає можливість учня обирати гуртки та секції в залежності від інтересів (гімнастика, плавання, ораторська майстерність тощо).

Проведений аналіз дозволяє зробити наступні висновки: хоумскулерами (учнями, які здобувають освіту вдома) найчастіше стають діти фрілансерів, які часто подорожують; за опитуваннями батьків дітей хоумскулерів, більше $90 \% 3$ них вважають, що сімейна освіта вирощує щасливих дітей: за умов домашнього навчання діти стають більш вільними. Процес прискорення темпів розвитку суспільства стимулює нове покоління значно швидше оброблювати інформацію, сімейна і домашня освіта дозволяють обирати темп, необхідний дитині і здавати атестацію екстерном. На ринку сімейної освіти велике значення мають як цінові, так і нецінові методи конкуренції (заклади освіти вступають в конкурентну боротьбу за потенційного учня ціновими та неціновими методами, при чому, що стосується альтернативних шкіл - як правило, неціновими методами, приватних для атестації - ціновими). У такому вигляді сімейна освіта має величезне значення в економіці знань і складає частину соціальної політики сучасного суспільства.

Висновки та перспективи подальших досліджень. Для підвищення якості сімейної освіти необхідна низка заходів: гармонізація системи освіти (координація вимог до знань учнів); підвищення ефективності системи освіти на основі зміни цілей і завдань освіти; іiі модернізації; перебудови системи керівництва; широкого впровадження інновацій у зміст навчального процесу; інтеграція системи освіти в Європейський простір (створення спільних навчальних закладів, розробка спільних навчальних програм, створення спільних дослідницьких інститутів, координація наукових досліджень і використання їхніх результатів); послідовний розвиток державної системи дошкільної освіти, що забезпечує всім дітям рівні можливості в отриманні освітніх послуг незалежно від соціального статусу, національності, вікових, статевих та фізіолого-психологічних особливостей; використання зарубіжного досвіду у створенні умов для запровадження знаннєвомістких технологій теорій людського та інтелектуального капіталу; підвищення престижу i фінансового забезпечення працівників «сектора знань»; створення стимулів для припливу талановитої молоді у науку і освіту; створення умов для проведення наукових досліджень у всіх формах сімейної освіти - загальноосвітніх закладах, закладах дошкільної та позашкільної освіти, в сім'ї - як важливішої ланки сімейної освіти; підвищення статусу вихователів та вчителів, покращення їхнього фінансового забезпечення; підвищення рівня мотивації та підтримка вчительських i виховательських ініціатив; розробка фінансового механізму соціального захисту дітей-інвалідів та дітей з малозабезпечених сімей, який передбачає фінансування їхнього навчання в альтернативних закладах освіти; створення умов для взаємодії місцевих органів влади, громадських організацій та батьківських спільнот, проведення форумів та інших заходів для обізнаності громадянбатьків, створення інформаційного простору всіх форм сімейної освіти регіону, пошуку методів підвищення якості освіти у регіоні; контроль за коштами, що виділяються державним та місцевим бюджетом на реалізацію регіональної освітньої політики із забезпечення якісної дошкільної та шкільної освіти; розробка пакету нормативноправових документів щодо отримання загальної освіти дітьми-хоумскулерами; залучення до розробки змісту освітніх програм та навчальних планів закладу представників різних громад, організацій, товариств, приватних організацій, що забезпечить створення альтернативних програм освіти; збагачення програм дошкільної освіти змістом, який формує толерантність у взаєминах з представниками різних 
національностей, релігійних конфесій тощо, духовність дітей дошкільного віку, сприяє їхній соціалізації; запозичення форм, методів та засобів організації педагогічного процесу; збагачення розвивального середовища навчальних закладів; розширення співпраці педагогів 3 батьками через урізноманітнення форм роботи 3 ними; використання принципу відкритості в роботі (діти не можуть постійно навчатися «за закритими дверима», батьки мають право відвідувати всі відкриті уроки; якщо заклад приватний - батьки мусять знати, за що сплачують свої кошти); посилення уваги до розвитку, виховання та навчання обдарованих дітей та дітей з особливими потребами через їх інклюзивне навчання; об'єднання у батьківські регіональні або районні спільноти з метою збору, обробки, обміну інформацією, відзивами, підручниками та навчально-методичними посібниками тощо; організація навчально-ігрового простору дітей за принципом шкіл-парків, де роль вчителів виконували б батьки, які мають відповідну освіту (досвід, знання тощо); створення творчого простору сімей (наприклад, проведення майстер-класів, сімейних ігор, квестів та інших заходів на відкритому просторі); впровадження банків часу з метою взаємного обміну послугами; активна участь у житті місцевої громади, форумах та конференціях з питань освіти та дитячого навчання.

Найважливішим фактором забезпечення ефективного розвитку економіки знань в Україні є стабілізація й поступове зміцнення політичної ситуації в країні, що $є$ індикатором розвитку всіх інших сфер.

\section{Література:}

1. Ажажа М.А. Інвестиції в освіту як фактор інтелектуального прогресу. Соціальна перспектива і регіональний розвиток: [наук.-пр. журн.]. Запоріжжя: ТОВ «КСК-Альянс». 2007. Випуск 2. С. 37-40.

2. Андрощук Г.А. Прогнозирование инновационной деятельности на основе анализа активности глобальных фирм. Проблеми науки. 2006. № 5. С. 40-47.

3. Білоцерківець В. В., Ляшенко А.В. Нова економіка: сутність та генеза. Дніпропетровськ. Січ. 2007. 221 с.

4. Гапоненко А.Л. Современный рынок знаний: понятие, участники, формы. Проблемы теории и практики управления. 2010. № 6. С. 55-64.

5. Геец В. М. Социально-экономические трансформации при переходе к экономике знаний. Социально-экономические проблемы информационного общества / под ред. д.э.н. Л.Г. Мельника. - Сумы: ИТД Университетская книга. 2004. 430 с.

6. Глухов В. В., Коробко С.Б., Маринина Т.В. Экономика знаний. Питер. 2003. $528 \mathrm{c}$

7. Давенпорт П. Канадские университеты и экономика знаний. Вестник Финансовой академии. 2000. № 1(13). С.40-45.

8. Захаров О. І. Управління знаннями у системі економічної безпеки суб'єктів господарської діяльності. Науковий вісник Львівського державного університету внутрішніх справ. серія економічна. 2012. Вип. 1. C. 39-47. URL: http://nbuv.gov.ua (дата звернення: 10.10 .2018 р.)

9. Мильнер Б.З. Управление знаниями: Эволюция и революция в организации. М. ИНФРА. 2003. 177 с.

10. Старовойт О.В. Економіка знань у стратегії інноваційного розвитку освіти: автореф. дис. канд. філософських наук. Київ. 2010. URL: http://osvitata.com/osvita-taekonomika (дата звернення: 05.10.2018р.) 
11. Степанов Ю. Экономика знаний или интеллектуальное общество? // Наша власть: дела и лица. - 2006. - №10. - С. 52-56.

12. Stewart T.A. Intellectual Capital: The New Wealth of Organization. New York: Doubleday/Currency. - 1997.

13. Федулова Л. І. Економіка знань / Л.І. Федулова; НАН України; Ін-т екон. та прогнозув. НАН України. - К., 2009. - 600 с.

14. Шульга Ж.О. Особливості економіки знань на сучасному етапі розвитку суспільства / Ж.О. Шульга // Вісник Бердянського університету менеджменту і бізнесу. - 2012. - № 1(17). - С. 94-99.

15. OECD Science, Technology and Industry Outlook. - OECD, 2010. [Електронний ресурс].- Режим доступу із: http://www.oecd.org/document/.

16. Світлична В. Л. Теоретичний базис нової парадигми суспільства - економіки знань / В. Л. Світлична // Економіка: реалії часу. - 2015. - № 3. - С. 184-193. [Електронний ресурс]. - Режим доступу: http://nbuv.gov.ua/UJRN/econrch_2015_3_29.

17. Подлужна Н.О. Систематизація підходів до визначення категорії «економіка знань» / Н.О. Подлужна // Наукові праці Кіровоградського національного технічного університету. Економічні науки. - 2016, вип.30. - С. 303-317.

18. Поляков М.В. Особливості економіки знань та їх прояви на рівні світового господарства / М.В. Поляков // Науковий вісник Ужгородського національного університету. - 2017. - №12(2). - С. 98-102.

19. Рак Н.С. Економіка знань: сутність та фактори управління знаннями / Н.С. Рак // Регіональна економіка. - 2009. - №3. - С. 224-232.

20. Гузар У.С. Економіка знань та іï перспективи для України / У.С. Гузар // Регіональна економіка. - 2009. - №11. - С. 25-32.

21. Хусаінов Р.В. Економіки знань: сутність, складові, специфіка / Р.В. Хусаінов, А.Ю. Янченко, М.М. Руденко // Молодий вчений. - 2015. - №11(26) - С. 99103.

22. Боярська М.О. Дослідження перспектив розвитку економіки знань в Україні / М.О. Боярська // Развитие производительных сил и региональная экономика. - 2014. № 5/2(19). - С. 57-61.

23. Іванова В.В. Економіка, заснована на знаннях, та економіка знань: адекватність використання категорій / В.В. Іванова // Механізм регулювання економіки. - 2011. - №3. - С. 47-54.

24. Мельник Л. Формування економіки знань, або принципи організації майбутнього / Л. Мельник // Вісник НАН України. - 2010. - № 6. - С. 19-28.

25. Лук'яненко Д. Імплементація парадигми економіки знань у стратегії національного економічного розвитку / Д.Лук'яненко, О.Лук'яненко, О.Дорошенко // Міжнародна економічна політика. - 2013. - № 2(19). - С. 5-26.

26. Букало Н.А. Економіка знань та заходи задоволення потреб споживачів у послугах вищої освіти / Н.А. Букало // Lviv Polytechnic National University Institutional [Електронний ресурс]. - Режим доступу: http://ena.lp.edu.ua

27. Семів Л. Університетська освіта в умовах переходу до економіки знань / Л. Семів, Р. Семів // Соціогуманітарні проблеми людини. - 2008. - №3. - С. 72-81.

28. Сагайдак-Нікітюк Р.В. Роль інтелектуальної ренти в економіці знань / Р.В. Сагайдак-Нікітюк, М.К. Коноваленко // Актуальні проблеми інноваційної економіки: Всеукраїнський науковий журнал. - 2016. - №2. - С. 48-54.

29. Усик В.І. Роль університету в секторній структурі економіки знань / В. I. Усик, Т.В. Матусевич // Інвестиції: практика та досвід. - 2017. - № 24. - С. 61-65. 